\title{
New Policies and Evaluation System Needed to Address Environmental Concerns in China
}

\author{
Zhe Liu $^{1, *}$ and Bertrum MacDonald ${ }^{2}$ \\ 1 Institute for Population and Development Studies, School of Public Policy and Administration, \\ Xi'an Jiaotong University, Shanxi Province 710049, China \\ 2 School for Information Management, Dalhousie University, Halifax, Nova Scotia B3H 4R2, Canada; \\ bertrum.macdonald@dal.ca \\ * Correspondence: zhe.liu@dal.ca
}

Received: 14 May 2020; Accepted: 12 June 2020; Published: 17 June 2020

\begin{abstract}
It is reported that the smog days in 2018 were much reduced compared to those in 2013 in China. The air environmental condition in China was much improved because of a number of comprehensive strategies adopted by the government such as phasing out backward production capacities and developing renewable energy industries. In addition, the Ministry of Ecology and Environment of the People's Republic of China adopted a series of measurements to respond to the environmental events, including questioning the local highest official in serious air pollution areas. However, there are still lots of questions to be answered for a long term consideration. For instance, given the current situation of a gross domestic production (GDP) driven assessment system for officials' credit, how long this high pressure pattern can respond to environmental events, such as air pollution, issue is a question. Therefore, unless this GDP driven assessment system is replaced by another assessment system it cannot last long. This paper also highlights the importance of developing low-carbon industries and circular economy as well as public involvement.
\end{abstract}

Keywords: air pollution; circular economy; policy

It is estimated that outdoor air pollution contributes to premature deaths in a range from 3.7 to 8.9 million persons annually [1]. Although this figure has not been confirmed, outdoor air pollution represents one of the greatest global risks to human health across the globe. As many as five years ago, as had been widely reported in the media in China and internationally, serious outdoor air pollution events like smog days had impacted the entire nation in China. Smog is a photochemical haze in the atmosphere with harmful air pollutants such as sulfide, oxides of nitrogen and others, which can cause respiratory diseases in human beings. Therefore, frequent smog days caused a lot of concern among the whole society. During that period, a lot of problems were exposed to be attributable to the serious smog days. For instance, from the enterprises' perspective, in order to reduce the economic costs factories that had installed pollution control equipment, such as that for desulfurization, were reluctant to use it because it affected their financial outcome. Under some circumstances, they might only operate the equipment when inspectors arrived at the plant. In others, they might not operate the equipment at night when inspectors of the environmental protection agency were not making observations, which led to actual emissions always being much higher than government regulatory agencies expected [2]. In addition, from the managements' perspective, the penalties for environmental pollution were not severe enough to cause factory managers to balance environmental and social responsibilities with economic benefits. Under such circumstances, factory managers would pay for fines for their excessive discharge rather than dealing with their excessive emissions.

In order to improve the air's environmental condition, a number of comprehensive strategies were adopted by the Chinese government, such as phasing out backward production capacities and 
developing renewable energy industries. For instance, in the past five years, the ratio of fossil energy application was reduced by $8.1 \%$, while the ratio of clean energy application was increased by $6.3 \%$. 1.8 million vehicles of new energy were produced to replace traditional fuel cars. Moreover, 62 thousand enterprises were punished for their excessive discharge. According to the latest statistic released by the Ministry of Ecology and Environment of the People's Republic of China (MEE), the smog days in 2018 were much reduced compared to those in 2013. For instance, the smog days in the Beijing area and in the Shanghai area were reduced by 30 days and 50 days, respectively. The air's environmental qualities in other regions in China have been improved in varying degrees in the past five years [3]. From the administrative measurement perspective, it has also been noticed that, in recent years, MEE has adopted a series of measurements to respond to environmental events, including questioning the local highest official in serious air pollution areas. MEE adopted manners like face to face interviews etc. to press local officials who were held accountable for local serious air pollution. This is a positive move to fight against air pollution, which forces local officials to face the current serious environmental issue rather than ignoring it like ever before.

It can be seen that significant progress with regards to environmental protection has been achieved in the past five years in China. However, there are still lots of questions to be answered for a long term consideration. For instance, given the current situation of a gross domestic production (GDP) driven assessment system for officials' credit, how long this high pressure pattern can respond to environmental events such as air pollution issue is a question. Therefore, unless this GDP driven assessment system is replaced by another assessment system, it cannot last long. The green GDP assessment indicator system was proposed by scholars several years ago, which means that resource and environmental loss should be included in GDP. Green GDP calculations can contribute to raising awareness for sustainability concerns among national governments/policy-makers, who tend to concentrate on their countries' fast economic development [4]. However, in this regard, the standards, rules and criteria should be further discussed from a practical perspective. If a proper green GDP system would be an assessment system for officials' credit, that would forcibly boost industrial promotion from local areas. Apart from the official perspective, public involvement, in particular in the inspection process for environmental events, would be helpful in spotting environmental events. The involvement pattern could be establishing an anonymous tip line to allow people to "blow the whistle" on polluters, especially those who turn off equipment or emit at night. This inspection and enforcement arrangement could involve some kind of reward when fines are levied against polluters, which can supplement the lack of resource distribution from the governmental perspective. In addition, establishing an independent, arms-length environmental protection agency for inspections and enforcement would be also viable. The effective inspection would be helpful in reducing incidents from happening such as the Tianjin Binhai area blast and the Xiangshui chemical blast in Jiangsu province in China [5], which caused serious losses in terms of human lives and environmental damage. In addition, raising penalties to force managers to put more emphasis on environmental responsibilities is also needed.

From the operational perspective, the government should keep on putting greater priority on the development of low-carbon industries and circular economy (CE) to replace the energy-intensive in the future. The Ministry of Industry and Information Technology in China released national low-carbon industrial park indicators in 2013 in order to address the increasing concerns on climate change [6]. In the past ten years, China has implemented CE policies at various scales: the micro level, i.e., individual processes or companies; the meso level, i.e industrial clusters or eco-industrial parks; and the macro level, ie. ranging from cities to national economies [7]. The development of low-carbon industries and CE are also environmental initiatives central to the "ecological civilization" strategy proposed by China's policy makers a decade ago and have been selected as a national development strategy, linking environmental and economic development. If it is implemented effectively, economic development without environmental degradation will be a realistic possibility.

Author Contributions: Conceptualization, Z.L. and B.M.; methodology, Z.L.; validation, B.M., formal analysis, Z.L.; investigation, Z.L.; resources, Z.L.; data curation, Z.L; writing-original draft preparation, Z.L.; writing-review 
and editing, B.M.; visualization, Z.L.; supervision, B.M.; project administration, Z.L.; funding acquisition, Z.L. All authors have read and agreed to the published version of the manuscript.

Funding: This study was supported by Youth Talent Fund (0123/712110510701) from Xi'an Jiaotong University, China.

Acknowledgments: We want to thank those anonymous reviewers for their valuable comments to the revised version of this paper.

Conflicts of Interest: The authors declare no conflict of interest.

\section{References}

1. Alain, R. An overview of selected emerging outdoor airborne pollutants and air quality issues: The need to reduce uncertainty about environmental and human impacts. J. Air Waste Manag. Assoc. 2020, 70, 341-378.

2. Smog News Investigation. Under The Dome. 28 February 2015. Available online: https://www.youtube.com/ watch?v=xbK4KeD2ajI (accessed on 20 June 2019).

3. Xinhua News Agency Client. Changes of Blue Sky in the Past Five Years. Xinhua News, 19 January 2019. Available online: http://www.xinhuanet.com/politics/2019-01/19/c_1124013050.htm (accessed on 20 June 2019).

4. Rounaghi, M.M. Economic analysis of using green accounting and environmental accounting to identify environmental costs and sustainability indicators. Int. J. Ethics Syst. 2019, 35, 504-512.

5. BBC. Nearly 100 people have died in the explosion of a chemical plant in Jiangsu, China. BBC, 23 March 2019. Available online: https://www.bbc.com/zhongwen/simp/chinese-news-47653430 (accessed on 10 January 2020).

6. Liu, Z.; Geng, Y.; Sergio, U.; Park, H.S.; Fujita, T.; Wang, H. Uncovering key factors influencing one industrial park's sustainability: A combined evaluation method of emergy analysis and index decomposition analysis. J. Clean. Prod. 2016, 114, 141-149.

7. Liu, Z.; Adams, M.; Cote, R.P.; Chen, Q.H.; Wu, R.; Wen, Z.G.; Liu, W.L.; Dong, L. How does circular economy respond to carbon dioxide emissions mitigation: An analysis of Chinese recycling plastic industry. Renew. Sustain. Energy Rev. 2018, 91, 1162-1169.

(C) 2020 by the authors. Licensee MDPI, Basel, Switzerland. This article is an open access article distributed under the terms and conditions of the Creative Commons Attribution (CC BY) license (http://creativecommons.org/licenses/by/4.0/). 